\title{
Patient attrition in Molecular Tumour Boards: A Review
}

\author{
Hannah Frost ${ }^{1,3}$, Donna M. Graham ${ }^{1,2}$, Louise Carter ${ }^{2}$, Paul O'Regan ${ }^{1}$, Donal Landers ${ }^{1}$ and \\ Andre Freitas ${ }^{1,3,4}$.

\begin{abstract}
${ }^{1}$ Digital Experimental Cancer Medicine Team, Cancer Research UK Manchester Institute, United Kingdom, ${ }^{2}$ The Christie NHS Foundation Trust, United Kingdom, ${ }^{3}$ Department of Computer Science, University of Manchester, United Kingdom, ${ }^{4}$ Idiap Research Institute, Switzerland.
\end{abstract}

This work was supported by the AstraZeneca iDECIDE Programme (grant no. 119106) awarded to Manchester Cancer Research Centre and Cancer Research UK (CRUK), Associazione Italiana per la Ricerca sul Cancro (AIRC) and Fundacion Científica - Asociacion Espanola Contra el Cancer (FC -AECC), via an Accelerator Award [A29374] through the CRUK Manchester Institute [C147/A25254].

\section{Abstract}

Molecular Tumour Boards (MTBs) were created with the purpose of supporting clinical decision making within precision medicine. Though these meetings are in use globally reporting often focuses on the small percentages of patients that receive treatment via this process and are less likely to report on, and assess, patients who do not receive treatment. A literature review was performed to understand patient attrition within MTBs and barriers to patients receiving treatment. A total of 54 papers were reviewed spanning a 6 year period from 11 different countries. $20 \%$ of patients received treatment through the MTB process. Of those that did not receive treatment the main reasons were no mutations identified (26\%), no actionable mutations (22\%) and clinical deterioration (15\%). However, the data was often incomplete due to inconsistent reporting of MTBs with only $53 \%$ reporting on patients having no mutations, $48 \%$ reporting on presence of actionable mutations with no treatment options and $57 \%$ reporting on clinical deterioration. As patient attrition in MTBs is an issue which is very rarely alluded to in reporting, more transparent reporting is needed to understand barriers to treatment and integration of new technologies is required to process increasing omic and treatment data.

\section{Introduction}

The human genome project provided the world with a fully referenced genome that helped to illuminate the role of somatic and germline mutations in the pathogenesis of cancer ${ }^{1}$. The development of next generation sequencing (NGS) propelled genomics research even further, enabling sequencing of entire genomes within days rather than decades. This helped facilitate the use of genomics sequencing within clinically meaningful timelines and identify aberrant pathways for the development of new and effective targeted treatment options for patients ${ }^{2}$, facilitating rapid precision medicine on a larger scale ${ }^{3}$. Precision medicine is a

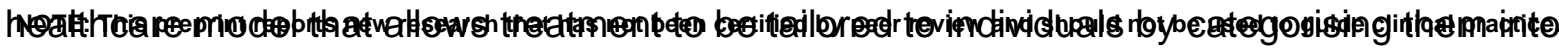


medRxiv preprint doi: https://doi.org/10.1101/2021.10.07.21264241; this version posted December 9,2021 . The copyright holder for this preprint (which was not certified by peer review) is the author/funder, who has granted medRxiv a license to display the preprint in

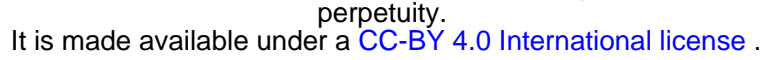

subpopulations ${ }^{4}$. Precision medicine is reliant on the knowledge and expertise of coordinating specialities, requiring persistent adoption of rapidly advancing science and new techniques.

Targeted therapies are drugs that target specific genes or proteins in cancerous cells ${ }^{5}$. Lung cancer treatment has had a number of successes with targeted therapy; drugs targeting EGFR mutations and ALK and ROS1 translocations are now routinely used in cancer treatment ${ }^{6}$. However, precision medicine successes aren't straightforward, for example, before the MET inhibitor Crizotinib was licenced for use in ALK translocations, it was originally tested in MET mutated tumours ${ }^{7}$. Despite having potent activity against MET ${ }^{8}$, studies found no anti-tumour effect in tumours with MET mutations ${ }^{9}$. Often determining appropriate targeted therapies for patients with pathogenic mutations requires input from multiple disciplines, therefore, organisations regularly consult with or develop Molecular Tumour Boards (MTB). Molecular Tumour Boards, Precision Genomics Boards or Genomics Review Boards are all names for a multidisciplinary team that consult on individual patients' treatment options either providing expert opinion to healthcare professionals who have limited access to multidisciplinary expertise or driving decisions for their own patients. These meetings focus on patients with rare, hard-to-treat or late stage malignant disease and are composed of various specialists but always include oncologists or clinicians and scientists or biologists $^{10,11,20-29,12,30-39,13,40-49,14,50-59,15,60-63,16-19}$. Clinical research has shown that these teams can help facilitate precision medicine, however, with increased evaluation limitations have emerged ${ }^{64,65}$.

MTBs were developed for the specific purpose of supporting complex clinical decision making and are often only reported in terms of positive outcomes. However, it is imperative that we are cognisant of the outcomes of patients who never reach the treatment phase on these pathways, to ensure that we are striving to improve processes and therefore opportunities for patients. This review aims to assess how global MTBs are conducted and identify common reasons for lack of treatment options, evaluating whether there are procedural issues that contribute to this attrition and areas for potential process optimisation. Additionally, suggested guidelines for the future reporting of MTBs may be informed by this review.

These guidelines could allow for transparent and consistent reporting, bringing awareness to deficiencies in the current system and facilitating change to mitigate against attrition and to ensure that all patients are given the greatest opportunity to access treatments.

The contribution of this paper is:

- Quantification of the issues with MTBs.

- A description of the reasons for patient attrition in an MTB.

- Recommendations for guidelines for optimal reporting of MTBs. 
medRxiv preprint doi: https://doi.org/10.1101/2021.10.07.21264241; this version posted December 9,2021 . The copyright holder for this preprint (which was not certified by peer review) is the author/funder, who has granted medRxiv a license to display the preprint in

\section{Methodology}

\section{Literature Based Analysis}

A review of published literature was performed to evaluate current MTB processes and understand the reasons a treatment option is not identified or accessed by a patient after review in an MTB. Databases searched were EMBASE and PubMed, and last accessed 19 November 2020. Search terms were formalised for reproducibility purposes.

Table 1 Search terms used in this review for both PubMed and EMBASE.

\begin{tabular}{|c|c|}
\hline Database & Search Terms \\
\hline PubMed & $\begin{array}{c}\text { (((((study).ti,ab OR (trial).ti,ab) AND (review).ti,ab) AND ((cancer).ti,ab OR } \\
\text { (oncology).ti,ab OR (tumour).ti,ab)) AND ((precision medicine).ti,ab OR } \\
\text { (molecular tumour board).ti,ab OR (Institutional Review Board).ti,ab)) } \\
\text { AND ((genomic profiling).ti,ab OR (precision oncology).ti,ab)" }\end{array}$ \\
\hline EMBASE & $\begin{array}{l}\text { "(((genomic profiling).ti,ab OR "PERSONALIZED MEDICINE"/ OR } \\
\text { (precision medicine).ti,ab OR (molecular tumour board).ti,ab OR } \\
\text { (precision oncology).ti,ab) AND ("STUDY, PILOT"/ OR "STUDY, SINGLE } \\
\text { BLIND"/ OR "STUDY,MULTICENTER"/ OR "STUDY,PROSPECTIVE"/ OR } \\
\text { (study).ti,ab OR (trial).ti,ab OR "CLINICAL TRIAL"/ OR "ADAPTIVE } \\
\text { CLINICAL TRIAL"/ OR "CONTROLLED CLINICAL TRIAL"/ OR } \\
\text { "MULTICENTER STUDY"/ OR "PHASE 1 CLINICAL TRIAL"/ OR "PHASE } \\
2 \text { CLINICAL TRIAL"/ OR "PHASE } 3 \text { CLINICAL TRIAL"/ OR "PHASE } 4 \\
\text { CLINICAL TRIAL"/ OR "CLINICAL TRIAL (TOPIC)"/)) AND (NEOPLASM/ } \\
\text { OR "MALIGNANT NEOPLASM"/ OR "ADVANCED CANCER"/ OR } \\
\text { "CHILDHOOD CANCER"/ OR "MULTIPLE CANCER"/ OR "PRIMARY } \\
\text { TUMOR"/ OR "SECOND CANCER"/ OR "SOLID MALIGNANT } \\
\text { NEOPLASM"/ OR "MALIGNANT NEOPLASM,SOLID"/ OR "MALIGNANT } \\
\text { NEOPLASTIC DISEASE"/ OR (cancer).ti,ab OR (tumour).ti,ab OR } \\
\text { ONCOLOGY/)) [DT 2020-2015] [Publication types Article OR Conference } \\
\text { Abstract OR Conference Paper OR Conference Proceeding OR } \\
\text { Conference Review OR Editorial OR Erratum OR Journal OR Report OR } \\
\text { Review OR Short Survey OR Trade Journal] [English language] } \\
\text { [Languages English] [Humans]" }\end{array}$ \\
\hline
\end{tabular}

Inclusion criteria were:

- written in English.

- more than five patients were reviewed through the MTB 
medRxiv preprint doi: https://doi.org/10.1101/2021.10.07.21264241; this version posted December 9,2021 . The copyright holder for this preprint (which was not certified by peer review) is the author/funder, who has granted medRxiv a license to display the preprint in

- multi-gene panel

- humans only

- and MTBs were either self-identified by the authors of the paper or were defined as a multidisciplinary team meeting that performed and reviewed multi-omic testing outside of standard of care, on patients with cancer, with an aim to finding a targeted therapy.

Exclusion criteria were:

- studies earlier than 2014

- non-oncology studies

- case studies

- imaging studies

- biomarker reviews

- evaluated specific treatment regimens or focused on specific mutations only

- an abstract, unless it supported a full paper

- had no centralised review of patients e.g., MTB

- no intention to treat

- or reported only in percentages making total numbers impossible to determine.

The country the MTB was based was recorded as well as the type of institution the MTB was held at, eligible cancer types, duration of the MTB, method of genomic testing performed, variant allele fraction threshold for action, and reasoning why patients were unable to access treatments.

Where numbers were unclear or reasons for attrition were grouped these were excluded from the analysis.

\section{Process Flow}

Using the papers selected for review a systematic formalisation of the MTB process was created using papers which described their MTB patient pathway. At the end of the review all process flows were assimilated to create a universal structure. The flows included the patient journey from consent to tissue acquisition and analysis, the point at which patients were discussed at an MTB, the return of their full genomic results and how the results were disseminated.

The following categories for attrition were identified from the review: insufficient tissue; no mutations identified; no actionable mutations identified; actionable mutations identified but no treatment available; actionable mutations identified by ineligible for treatment; patient had already received the matched drug; off licence treatment available but couldn't access; clinically deteriorated and patients were categorised accordingly. As each study did not report on all these categories there were multiple missing data points.

\section{Statistical analysis}

Descriptive statistics only are provided due to the number of missing data points a more formal statistical review was deemed inappropriate. Patient attrition is described using 
medRxiv preprint doi: https://doi.org/10.1101/2021.10.07.21264241; this version posted December 9, 2021. The copyright holder for this preprint (which was not certified by peer review) is the author/funder, who has granted medRxiv a license to display the preprint in

It is made available under a CC-BY 4.0 International license.

percentages, as all papers did not report on each reason for attrition the percentages were derived only from papers that reported on them.

\section{Results}

A literature review gave a fuller understanding of the global picture for patients and provided insight on the perceived importance by researchers of patient attrition. The review produced over 8000 targeted results (EMBASE 115/ PubMed 7888) which was reduced to 54 evaluable papers using the exclusion and inclusion criteria listed in the methods. All reviews and data collection were performed by a single reviewer.

\section{Study Characteristics}

A summary of MTB characteristics can be found in Table 1. Exactly half of all studies enrolled 100 patients or fewer to an MTB, with an overall range of 14-3737. The average study length was 29 months (range 6-60 months).

Table 2 Summary of MTB characteristics

\begin{tabular}{|l|l|}
\hline Category & Papers \\
\hline Total number of Papers & 54 \\
\hline Year, No. & \\
\hline 2014 & 1 \\
2015 & 5 \\
2016 & 9 \\
2017 & 13 \\
2018 & 7 \\
2019 & 15 \\
2020 & 4 \\
\hline Country, No. & \\
\hline USA & 29 \\
France & 9 \\
UK & 4 \\
Germany & 3 \\
Austria & 2 \\
Australia & 1 \\
\hline &
\end{tabular}




\begin{tabular}{|l|l|l|} 
Belgium & 1 \\
Canada & 1 \\
Norway & 1 \\
Singapore & 1 \\
Switzerland & 1 \\
NS & \\
\hline Cancer type, No. & 34 \\
\hline $\begin{array}{l}\text { Adult only patients with Mixed } \\
\text { tumour types }\end{array}$ & $\mid 4$ \\
Haematological & 4 \\
$\begin{array}{l}\text { Paediatric only patients with Mixed } \\
\text { tumour types }\end{array}$ & 4 \\
$\begin{array}{l}\text { Colorectal } \\
\text { Gynaecological }\end{array}$ & $\mid 3$ \\
\hline $\begin{array}{l}\text { Breast } \\
\text { Lung }\end{array}$ & $\mid 2$ \\
$\begin{array}{l}\text { Both Adult and Paediatric patients } \\
\text { with mixed tumour types }\end{array}$ & 2 \\
$\begin{array}{l}\text { Glioblastoma } \\
\text { Lymphoma }\end{array}$ & 1 \\
Neuroblastoma & 1 \\
\hline
\end{tabular}

\section{Process Flow}

The overarching process flow was used to identify steps in the process where there is typically patient attrition (figure 1). Few MTBs had unique processes, those that did differ varied by bioinformatic pipeline and whether patients were presented to the MTB before and after profiling or after only. Other areas where MTBs differed were in how the results were disseminated. This was typically done in one or more of the following routes; through an online database; via patient health records; through email or phone call to the patient; or within a report given to the treating clinician.

\section{Patient Attrition}

A total of 19686 cases were described within the selected papers. Of these the majority were adults $(n=16427)$, with 628 childhood cancer cases reported. 2631 cases were reported in a mixed adult and paediatric MTB. The reasons for not receiving therapy were inconsistently 
medRxiv preprint doi: https://doi.org/10.1101/2021.10.07.21264241; this version posted December 9, 2021. The copyright holder for this preprint (which was not certified by peer review) is the author/funder, who has granted medRxiv a license to display the preprint in perpetuity.

It is made available under a CC-BY 4.0 International license.

reported in the published literature and patient numbers reduced without explanation (unknown outcome $n=5725$, see Figure 2 ), therefore there is variability in data available for patient outcomes. Of those cases where the outcome was known, the most common reasons reported for patient attrition were: no mutations detected $(26 \%)$, no actionable mutations detected (22\%), clinical deterioration (15\%) or lack of tissue (13\%). The reason for the greatest number of patients not receiving treatment in paediatric trials (14\%) was no actionable mutations, whereas in adult trials these were no mutations and no actionable mutations. 
medRxiv preprint doi: https://doi.org/10.1101/2021.10.07.21264241; this version posted December 9, 2021. The copyright holder for this preprint (which was not certified by peer review) is the author/funder, who has granted medRxiv a license to display the preprint in

perpetuity.
It is made available under a CC-BY 4.0 International license .

Insufficient tissue

Studies reporting $n=32$

Patient attrition $14 \%$

\section{No mutations}

Studies reporting $\mathrm{n}=29$

Patient attrition $26 \%$

No Actionable mutations

Studies reporting $\mathrm{n}=26$

Patient attrition $22 \%$

Actionable but not treatment/

trial available

Studies reporting $n=16$

Patient attrition $6 \%$

Actionable but ineligible for

treatment

Studies reporting $n=17$

Patient attrition $4 \%$

Off-licence treatment available

but not accessed

Studies reporting $n=7$

Patient attrition 5\%

Actionable mutations

Studies reporting $n=45$

Patient attrition $49 \%$

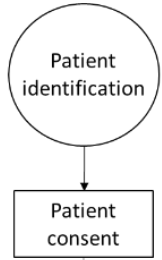

Yes

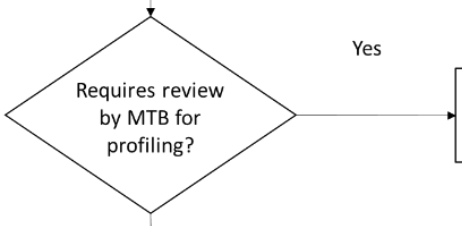

No

Review by MTB to determine eligibility for molecular profiling

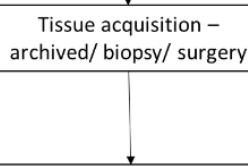

e.g. Blood/ Buccal
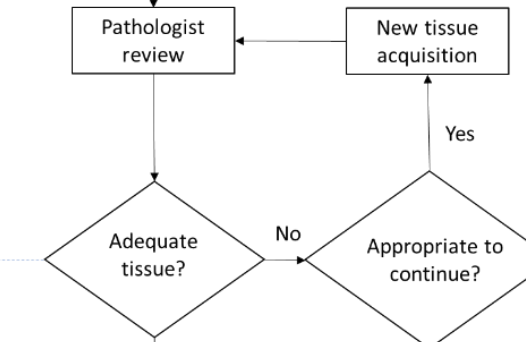

Yes enomic testing

Yes Eligible for profiling?

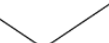

$\mathrm{n}=31$

Patient attrition 15\%
Patients treated

Studies reporting $n=48$

Percentage of patients $20 \%$

Figure 1 Process flow for MTBs globally with common reasons for attrition. As not all studies reported on all the reasons outlined in this review percentages were calculated out of the studies where the data was available. Abbrevations: MTB Molecular tumour board, QA Quality assurance. 
medRxiv preprint doi: https://doi.org/10.1101/2021.10.07.21264241; this version posted December 9, 2021. The copyright holder for this preprint (which was not certified by peer review) is the author/funder, who has granted medRxiv a license to display the preprint in perpetuity.

It is made available under a CC-BY 4.0 International license .

In MTBs describing adult patients 20\% (3333/16427) went onto treatment; in paediatric studies, $13 \%(81 / 628)$ of patients went on to treatment, and in MTBs where patient populations were both adults and paediatrics $7 \%$ (173/2631) went onto treatment. The greatest rates of attrition were due to clinical deterioration, no mutations detected, or no actionable mutations detected.

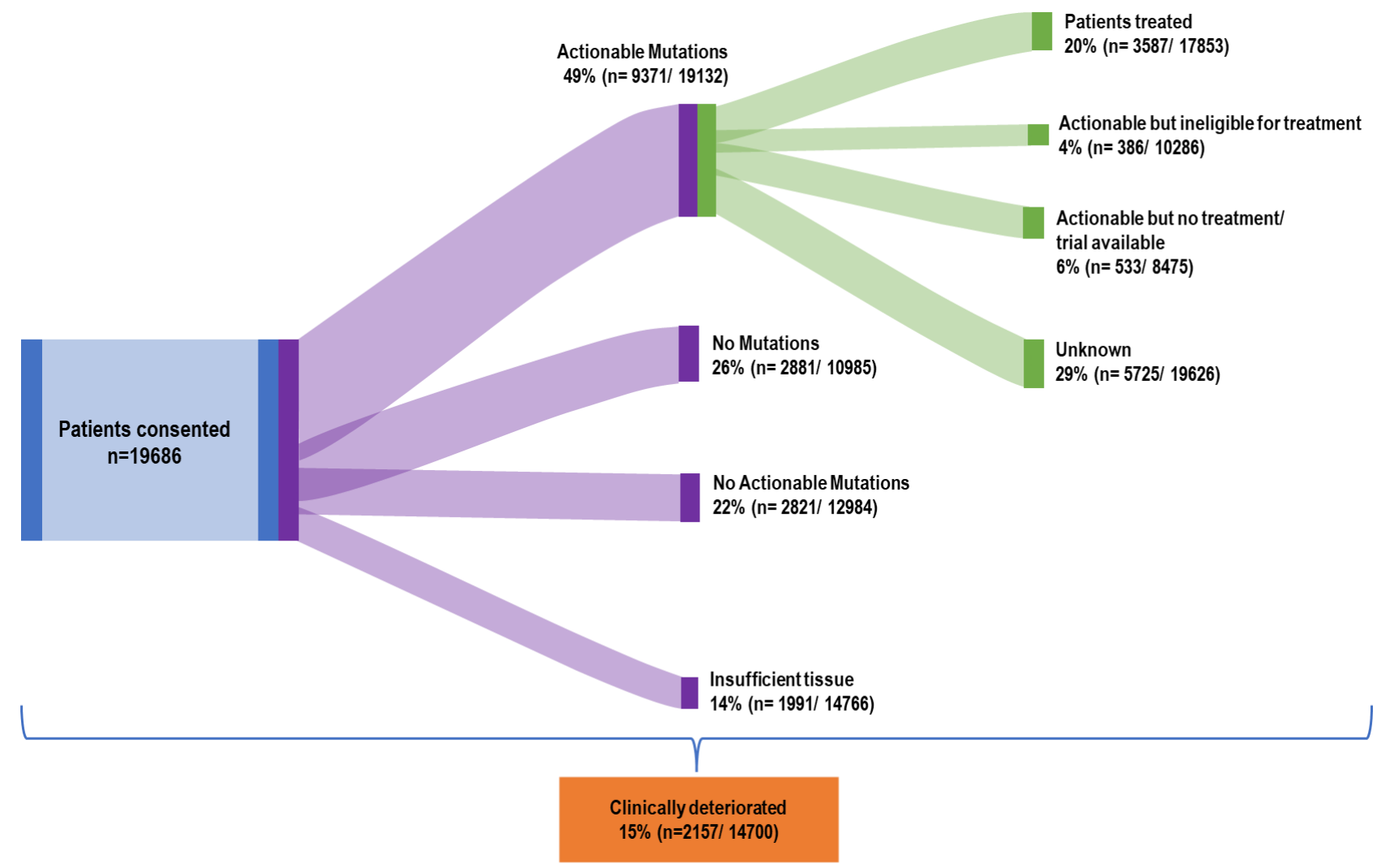

Figure 2 Flow of patients in all studies through an MTB, numbers and percentage are no cumulative as some studies did not report on all reasons for attrition. Clinical deterioration occurred at any stage of the patient journey, and it was not possible to separate these stages out.

\section{Reporting of MTBs}

MTBs were inconsistently reported in the literature. Although arguably reasons for patient attrition may vary, some studies failed to report on the number of patients evaluated by an $\operatorname{MTB}(n=1)$ and the number of patients treated based on recommendations by MTBs $(n=5)$. Also missing were the composition of the MTB $(n=13)$ and tissue type used for sequencing $(n=14)$. Only 12 MTBs reported on the presence or absence of a cut off for variant allele frequency and 15 reported on what actionability scales were used. Outlined in Figure 1 are the areas in the process where patient attrition occurs and how often this was reported in the literature. Of the data that was available overall $49 \%$ of patients had an actionable mutation after genomic profiling and $20 \%$ of all patients registered to MTB received recommended treatment. There were no studies that reported on all areas defined in this review. 
medRxiv preprint doi: https://doi.org/10.1101/2021.10.07.21264241; this version posted December 9,2021 . The copyright holder for this preprint (which was not certified by peer review) is the author/funder, who has granted medRxiv a license to display the preprint in perpetuity.

It is made available under a CC-BY 4.0 International license .

Table 3 Percentage of papers reporting on specific attrition reasoning within the literature.

\begin{tabular}{|l|l|}
\hline Patient outcome & $\begin{array}{l}\text { Percentage of full } \\
\text { papers reporting on } \\
\text { outcome ( } \mathbf{n}=54)\end{array}$ \\
\hline Patients with actionable mutations & $87 \%$ \\
\hline Patients with insufficient tissue for analysis & $62 \%$ \\
\hline Patients with no mutations identified & $56 \%$ \\
\hline Patients with no actionable mutations as deemed by the MTB & $50 \%$ \\
\hline $\begin{array}{l}\text { Patients with actionable mutations but no treatment/ clinical trials } \\
\text { available }\end{array}$ & $31 \%$ \\
\hline $\begin{array}{l}\text { Patients with actionable mutations who aren't eligible for } \\
\text { treatment }\end{array}$ & $33 \%$ \\
\hline Patients received recommended treatment previously & $12 \%$ \\
\hline Off licence treatments available but unable to access & $14 \%$ \\
\hline Off licence treatment available and accessed & $17 \%$ \\
\hline Patient clinically deteriorated & $60 \%$ \\
\hline Patients treated based upon MTB recommendations & $92 \%$ \\
\hline
\end{tabular}

\section{Discussion}

Molecular tumour boards were developed to assist with assessment of genomic tests to facilitate targeted treatment for patients and have been widely implemented throughout the globe. On average $20 \%$ of patients enrolled onto an MTB received an MTB-directed therapy. When able to access treatment, overall response rates vary from $0 \%-67 \%$ and MTBs at best "do no harm"66. MTBs facilitate enrolment of patients on to treatments or trials with biological potential or for their specific tumour type, some may argue that it gives patients the chance, however small, to receive life extending drugs. However, with attrition rates exceedingly high and response rates variable, one patient in 5 will have the opportunity to access a targeted therapy after exhausting standard of care.

As we elicited, there are two key areas of issue with treating patients through an MTB, there are high rates of patient attrition, and secondly there are low response rates. Clinical outcomes are out of the scope of this review, though are covered in detail by Larson et al. ${ }^{66}$ 
medRxiv preprint doi: https://doi.org/10.1101/2021.10.07.21264241; this version posted December 9,2021 . The copyright holder for this preprint (which was not certified by peer review) is the author/funder, who has granted medRxiv a license to display the preprint in

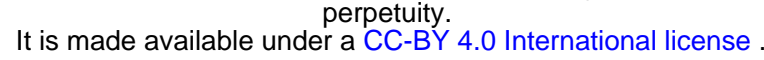

Patient attrition can be summarised into broad categories such as, lack of suitable tissue; no mutations; or actionable mutations but unable to access treatment as not available or; unable to access treatment even though available; and clinical deterioration. Practically addressing specific blockers could facilitate more patients gaining access to treatment, which we address in the following sections.

\section{Points of Intervention}

\section{Lack of tissue}

All studies in this review, where the sample type used for profiling was specified, used either archived tissue samples, fresh biopsy, or surgical samples as the source of tumour profiling. Where blood samples were taken, this was usually only for germline analysis. Insufficient tissue was one of the most common reasons provided for patient attrition and comprised $14 \%$ of all patients $(n=1991)$ in this review. This did not include numbers of patients that were ineligible based upon lack of tissue as they were never enrolled in the MTB. However, to put this into context and highlight the proportion of patients this may omit, in one study alone 3290 patients failed screening due to a lack of tissue and just 229 were enrolled ${ }^{20}$.

Liquid biopsies have been a long awaited tool in oncology. They have been shown to be clinically relevant for different cancer types though there is still much work left to do until they can be utilised routinely by oncologists. ${ }^{67,68}$ However, there is a clear need for alternatives to tissue analysis. Of the four studies that looked at using liquid biopsy for genomic analysis turnaround time data is not available but only $4 \%$ (range $0-8 \%$ ) of patients were ineligible due to a lack of or failure of a sample ${ }^{12,16,50,55}$ compared to $14 \%$ (range $0-23 \%$ ) where analysis failed when only tissue was used (see Supplementary Material table 1). Circulating free tumour derived DNA can be used for the assessment of cancer-specific somatic mutations, chromosomal abnormalities, copy-number alterations and epigenetic modifications and is elevated in malignancy ${ }^{69}$. It has been shown to be useful in therapy selection for patients, particularly in settings where patients are late stage ${ }^{70,71}$. Furthermore, the downsides to tumour biopsies are well documented ${ }^{72}$ and retrieving archived samples can often cause significant delays. Implementing more wide-scale liquid biopsy testing could improve the rates of attrition where patients are lacking sufficient tissue, are unsuitable for biopsy or have old archival samples.

\section{No actionable mutations or no mutations}

The two greatest reasons for patient attrition within this review were that patients' sample yielded no mutations or no actionable mutations as determined by the reviewing MTB. It has been shown that more comprehensive multi-omics profiling provides more clinically relevant information ${ }^{73-75}$, however, it is necessary to couple this with technologies that will help to prioritise the inevitable volumes of information produced ${ }^{76}$.

The number of patients accessing treatment changes depending on the types and number of profiling tests that are performed on their sample (e.g. NGS, IHC RNAseq etc.). Interestingly there is an almost $50 \%$ decrease in treatment access when two tests are used, and treatment rates do not increase significantly the more complex testing is used (see supplementary material table 2). This could be potentially explained by a lack of drugs 
medRxiv preprint doi: https://doi.org/10.1101/2021.10.07.21264241; this version posted December $9,2021$. The copyright holder for this preprint (which was not certified by peer review) is the author/funder, who has granted medRxiv a license to display the preprint in

It is made available under a CC-BY 4.0 International license.

associated with these genomic alterations or possibly due to the increased challenge for clinicians at being able to discern potentially actionable mutations due to an excess of data. Developing computational methods to help integrate and interpret data from multiple tests to link with current literature and available treatment options could help to manage the demand on clinicians. A lack of drug availability is also a limiting factor that has the potential to get better over time ${ }^{77}$.

\section{Actionable mutations but ineligible or no options for treatment.}

Attrition due to ineligibility for clinical trials or no further treatment options available, both within a clinical trial or using off licence treatment, affected $15 \%$ of all patients in this review. However, this was only reported in $13 \%$ (off licence treatment available but unable to access) and $31-32 \%$ (actionable but no treatment/ trial available or ineligible for treatment) of studies so has the potential to impact greater numbers. Unsurprisingly, a common barrier to paediatric studies was gaining access to treatment options. Though drug development has increased in this area ${ }^{78}$ further work is being done in cancers where presentation in adults differs to children or paediatric-specific cancers ${ }^{79}$.

Eligibility criteria is important to ensure the safety of participants on clinical studies however it can be restrictive, resulting in unjustified exclusion of patients from enrolment into clinical trials $^{80-83}$. A systematic review of randomized controlled trials found that $47.2 \%$ of criteria were not scientifically justified ${ }^{82}$. Not only does this result in failed recruitment for studies but also fails to evaluate efficacy and safety in real world populations, and importantly excludes patients from receiving potential treatment options. Therefore, more flexible data-driven eligibility criteria are required to prevent unnecessary exclusion of patients from trials ${ }^{84,85}$, though this will require a wider consensus to drive this change. Importantly, artificial intelligence and machine learning can play a crucial role in evaluating suitable patients for studies that do not follow a restrictive exclusion/ inclusion approach ${ }^{83}$.

Identifying suitable treatment or trial options for patients can be a difficult and onerous task given the large number of recruiting studies, potentially actionable mutations and literature based evidence currently available, which is steadily growing ${ }^{86}$. Therefore, trial matching software can help clinicians review available studies based upon patients profiling results, ${ }^{87}$ not solely relying on clinicians' knowledge of local and available clinical trials. Some profiling services provide these trial matching services, such as Foundation Medicine ${ }^{88}$, though to date it is unclear how comprehensive or relevant these suggestions are for patients or how often these suggestions are implemented. Additionally, clinical trial slots for dose escalation studies are intermittently available or rapidly fill for small dose escalation cohorts so it is important to be able to capture this rapidly altering data.

Unfortunately, information on accessing off-licence treatment is unavailable, including how often drug applications are accepted or rejected.

\section{Patients clinically deteriorated}

One of the best reported outcomes was clinical deterioration of patients, whether that was declining performance status, admission to hospice care or death. By the nature of MTBs patients that are considered are often late stage, have rare cancers or poor prognosis. As a 
medRxiv preprint doi: https://doi.org/10.1101/2021.10.07.21264241; this version posted December $9,2021$. The copyright holder for this preprint (which was not certified by peer review) is the author/funder, who has granted medRxiv a license to display the preprint in

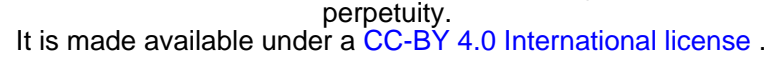

result, it is inevitable that they may decline during the process. However, accelerating the process of review will inevitably improve the chances of patients reviewed by MTBs, such as moving to liquid biopsies to reduce wait times for tissue acquisition and preparation or engaging with community teams that refer to the MTBs to facilitate earlier and more accurate referrals, thus decreasing the need for pre-sequencing MTB reviews to evaluate suitability for genomic testing.

\section{Standardised reporting}

In stark contrast to criteria for publishing on clinical trials ${ }^{89}$ there was no standard reporting for MTBs. This is evidenced by the difficulty in obtaining and analysing the data from this review due to the number of missing values. It is important to understand the reasoning behind patient attrition to be able to improve processes and understand barriers to access. Therefore, we suggest a broader community-level discussion on standardised reporting in MTBs. Additionally, providing standard reporting for researchers allow for accurate contrast of approaches, whether that is process or testing driven.

Aiming for a systematic and continuous assessment of attrition and opportunities for therapeutic evolution, we suggest the following categories as a minimum set; tissue type; testing performed; number and types of genetic changes included; variant allele frequency threshold; genomic scale used; number of patients registered to MTBs; number of patients with actionable mutations; attrition numbers and reasoning; total number of patients accessing treatment based on MTB review; and turnaround times from tissue acquisition to discussion at MTB.

\section{Conclusions}

Attrition within MTBs is a pervasive issue that is experienced globally, and as omics-derived data continues to increase alongside new targeted therapies and a growing literature base it is more important than ever to integrate new technologies to guide and aid clinicians in decision making. Consistent reporting is important to understand barriers to accessing treatment via MTBs and more work needs to be done to understand how often patients are unable to access off-licence treatment and clinical trials.

\section{References}

1. Wheeler, D. A. \& Wang, L. From human genome to cancer genome: The first decade. Genome Res. 23, 1054-1062 (2013).

2. Xuan, J., Yu, Y., Qing, T., Guo, L. \& Shi, L. Next-generation sequencing in the clinic: Promises and challenges. Cancer Lett. 340, 284-295 (2013).

3. Morganti, S. et al. Complexity of genome sequencing and reporting: Next generation sequencing (NGS) technologies and implementation of precision medicine in real life. Crit. Rev. Oncol. Hematol. 133, 171-182 (2019).

4. Ginsburg, G. S. \& Phillips, K. A. Precision Medicine: From Science To Value. Health Aff. 37, 694-701 (2018).

5. $\quad \mathrm{NIH}$. Targeted Therapy to Treat Cancer. (2020). Available at: https://www.cancer.gov/about-cancer/treatment/types/targeted-therapies. (Accessed: 1st October 2021) 
medRxiv preprint doi: https://doi.org/10.1101/2021.10.07.21264241; this version posted December 9,2021 . The copyright holder for this preprint (which was not certified by peer review) is the author/funder, who has granted medRxiv a license to display the preprint in perpetuity.

It is made available under a CC-BY 4.0 International license .

6. Normanno, N., Barberis, M., De Marinis, F. \& Gridelli, C. Molecular and Genomic Profiling of Lung Cancer in the Era of Precision Medicine: A Position Paper from the Italian Association of Thoracic Oncology (AIOT). Cancers (Basel). 12, 1627 (2020).

7. Blackhall, F. \& Cappuzzo, F. Crizotinib: from discovery to accelerated development to front-line treatment. Ann. Oncol. 27, iii35-iii41 (2016).

8. Drilon, A. et al. Antitumor activity of crizotinib in lung cancers harboring a MET exon 14 alteration. Nat. Med. 26, 47-51 (2020).

9. Tanizaki, J. et al. MET Tyrosine Kinase Inhibitor Crizotinib (PF-02341066) Shows Differential Antitumor Effects in Non-small Cell Lung Cancer According to MET Alterations. J. Thorac. Oncol. 6, 1624-1631 (2011).

10. Aust, S. et al. Precision medicine tumor boards: Clinical applicability of personalized treatment concepts in ovarian cancer. Cancers (Basel). 12, 1-13 (2020).

11. Basse, C. et al. Relevance of a molecular tumour board (MTB) for patients' enrolment in clinical trials: Experience of the Institut Curie. ESMO Open 3, 1-7 (2018).

12. Bohan, S. S. et al. Attrition of Patients on a Precision Oncology Trial: Analysis of the IPREDICT Experience. Oncologist 25, e1803-e1806 (2020).

13. Borad, M. J. et al. Clinical Implementation of Integrated Genomic Profiling in Patients with Advanced Cancers. Sci. Rep. 6, 1-12 (2016).

14. Bryce, A. H. et al. Experience with precision genomics and tumor board, indicates frequent target identification, but barriers to delivery. Oncotarget 8, 27145-27154 (2017).

15. Byron, S. A. et al. Prospective Feasibility Trial for Genomics-Informed Treatment in Recurrent and Progressive Glioblastoma. Clin. Cancer Res. 24, 295-305 (2018).

16. Choi, I. S. et al. Genomic profiling of blood-derived circulating tumor DNA from patients with colorectal cancer: Implications for response and resistance to targeted therapeutics. Mol. Cancer Ther. 18, 1852-1862 (2019).

17. Cousin, S. et al. Clinical impact of extensive molecular profiling in advanced cancer patients. J. Hematol. Oncol. 10, 1-3 (2017).

18. Dalton, W. B. et al. Personalized Medicine in the Oncology Clinic: Implementation and Outcomes of the Johns Hopkins Molecular Tumor Board. JCO Precis. Oncol. 1-19 (2017). doi:10.1200/po.16.00046

19. George, S. L. et al. A tailored molecular profiling programme for children with cancer to identify clinically actionable genetic alterations. Eur. J. Cancer 121, 224-235 (2019).

20. Ghazani, A. A. et al. Assigning clinical meaning to somatic and germ-line wholeexome sequencing data in a prospective cancer precision medicine study. Genet. Med. 19, 787-795 (2017).

21. Gunderson, C. C. et al. Initiation of a formalized precision medicine program in gynecologic oncology. Gynecol. Oncol. 141, 24-28 (2016).

22. Harada, S. et al. Implementation and utilization of the molecular tumor board to guide precision medicine. Oncotarget 8, 57845-57854 (2017).

23. Heong, V. et al. Value of a molecular screening program to support clinical trial enrollment in Asian cancer patients: The Integrated Molecular Analysis of Cancer (IMAC) Study. Int. J. Cancer 142, 1890-1900 (2018).

24. Hirshfield, K. M. et al. Clinical Actionability of Comprehensive Genomic Profiling for Management of Rare or Refractory Cancers. Oncologist 21, 1315-1325 (2016).

25. Horak, P. et al. Precision oncology based on omics data: The NCT Heidelberg experience. Int. J. Cancer 141, 877-886 (2017).

26. Kaderbhai, C. G. et al. Use of dedicated gene panel sequencing using next generation sequencing to improve the personalized care of lung cancer. Oncotarget 7 , 24860-24870 (2016).

27. Kapiris, M. et al. A retrospective analysis of 66 colorectal cancer cases from Guy's and St Thomas' (GSTT) Molecular Tumour Board. Ann. Oncol. 30, vii9 (2019).

28. Khater, F. et al. Molecular Profiling of Hard-to-Treat Childhood and Adolescent Cancers. JAMA Netw. open 2, e192906 (2019). 
medRxiv preprint doi: https://doi.org/10.1101/2021.10.07.21264241; this version posted December 9,2021 . The copyright holder for this preprint (which was not certified by peer review) is the author/funder, who has granted medRxiv a license to display the preprint in perpetuity.

It is made available under a CC-BY 4.0 International license .

29. Kieler, M. et al. Interim analysis of a real-world precision medicine platform for molecular profiling of metastatic or advanced cancers: MONDTI. ESMO Open 4, 1-10 (2019).

30. Koschmann, C. et al. Clinically Integrated Sequencing Alters Therapy in Children and Young Adults With High-Risk Glial Brain Tumors. JCO Precis. Oncol. 1-34 (2018). doi:10.1200/po.17.00133

31. Lamping, M. et al. Support of a molecular tumour board by an evidence-based decision management system for precision oncology. Eur. J. Cancer 127, 41-51 (2020).

32. Lane, B. R. et al. Development of a Center for Personalized Cancer Care at a Regional Cancer Center: Feasibility Trial of an Institutional Tumor Sequencing Advisory Board. J. Mol. Diagnostics 17, 695-704 (2015).

33. Lee, B. et al. Exploring the feasibility and utility of exome-scale tumour sequencing in a clinical setting. Intern. Med. J. 48, 786-794 (2018).

34. Loaiza-Bonilla, A., Kurnaz, S., Johnston, K., Culcuoglu, C. \& Arango, B. Feasibility of precision oncology virtual tumour boards to optimise direct point-of-care management and clinical trial enrolment of advanced cancer patients: New models for personalised oncology. Ann. Oncol. 28, vii7 (2017).

35. Marks, L. J. et al. Precision medicine in children and young adults with hematologic malignancies and blood disorders: The Columbia university experience. Front. Pediatr. 5, 1-15 (2017).

36. Massard, C. et al. High-throughput genomics and clinical outcome in hard-to-treat advanced cancers: Results of the MOSCATO 01 trial. Cancer Discov. 7, 586-595 (2017).

37. Meric-Bernstam, F. et al. Feasibility of large-scale genomic testing to facilitate enrollment onto genomically matched clinical trials. J. Clin. Oncol. 33, 2753-2762 (2015).

38. Moore, D. A. et al. Prospective analysis of 895 patients on a UK Genomics Review Board. ESMO Open 4, 1-10 (2019).

39. Oberg, J. A. et al. Implementation of next generation sequencing into pediatric hematology-oncology practice: Moving beyond actionable alterations. Genome Med. 8, 1-19 (2016).

40. Ortiz, M. V. et al. Integrating Genomics Into Clinical Pediatric Oncology Using the Molecular Tumor Board at the Memorial Sloan Kettering Cancer Center. Pediatr. Blood Cancer 63, 1368-1374 (2016).

41. Parker, B. A. et al. Breast cancer experience of the molecular tumor board at the University of California, San Diego moores cancer center. J. Oncol. Pract. 11, 442449 (2015).

42. Parsons, H. A. et al. Individualized Molecular Analyses Guide Efforts (IMAGE): A Prospective Study of Molecular Profiling of Tissue and Blood in Metastatic TripleNegative Breast Cancer. Clin. Cancer Res. 23, 379-386 (2017).

43. Pincez, T. et al. Feasibility and clinical integration of molecular profiling for target identification in pediatric solid tumors. Pediatr. Blood Cancer 64, 1-9 (2017).

44. Powell, S. F. et al. Delivering Precision Oncology in a Community Cancer Program: Results From a Prospective Observational Study. JCO Precis. Oncol. 1-12 (2018). doi:10.1200/po.17.00220

45. Réda, M. et al. Implementation and use of whole exome sequencing in daily practice for metastatic solid cancer. EBioMedicine 51, (2020).

46. Ree, A. H. et al. Implementing precision cancer medicine in the public health services of Norway: The diagnostic infrastructure and a cost estimate. ESMO Open 2, 1-9 (2017).

47. Rodon, J. et al. Genomic and transcriptomic profiling expands precision cancer medicine: the WINTHER trial. Nat. Med. 25, 751-758 (2019).

48. Rodriguez-Rodriguez, L. et al. Use of comprehensive genomic profiling to direct pointof-care management of patients with gynecologic cancers. Gynecol. Oncol. 141, 2-9 
medRxiv preprint doi: https://doi.org/10.1101/2021.10.07.21264241; this version posted December 9,2021 . The copyright holder for this preprint (which was not certified by peer review) is the author/funder, who has granted medRxiv a license to display the preprint in perpetuity.

It is made available under a CC-BY 4.0 International license .

(2016).

49. Rolfo, C. et al. Multidisciplinary molecular tumour board: A tool to improve clinical practice and selection accrual for clinical trials in patients with cancer. ESMO Open 3 , 1-8 (2018).

50. Rothwell, D. G. et al. Utility of ctDNA to support patient selection for early phase clinical trials: the TARGET study. Nat. Med. 25, 738-743 (2019).

51. Sadaps, M. et al. Precision Oncology in Solid Tumors: A Longitudinal Tertiary Care Center Experience. JCO Precis. Oncol. 1-11 (2018). doi:10.1200/po.18.00186

52. Sailer, V. et al. Integrative Molecular Analysis of Patients With Advanced and Metastatic Cancer. JCO Precis. Oncol. 1-12 (2019). doi:10.1200/po.19.00047

53. Saulnier Sholler, G. L. et al. Feasibility of implementing molecular-guided therapy for the treatment of patients with relapsed or refractory neuroblastoma. Cancer Med. $\mathbf{4}$, 871-886 (2015).

54. Schwaederle, M. et al. Molecular Tumor Board: The University of California San Diego Moores Cancer Center Experience. Oncologist 19, 631-636 (2014).

55. Sicklick, J. K. et al. Molecular profiling of cancer patients enables personalized combination therapy: the I-PREDICT study. Nat. Med. 25, 744-750 (2019).

56. Singer, F. et al. SwissMTB: Establishing comprehensive molecular cancer diagnostics in Swiss clinics. BMC Med. Inform. Decis. Mak. 18, 1-18 (2018).

57. Tafe, L. J. et al. Implementation of a Molecular Tumor Board: The Impact on Treatment Decisions for 35 Patients Evaluated at Dartmouth-Hitchcock Medical Center. Oncologist 20, 1011-1018 (2015).

58. Trédan, O. et al. Molecular screening program to select molecular-based recommended therapies for metastatic cancer patients: analysis from the ProfiLER trial. Ann. Oncol. 30, 757-765 (2019).

59. Trivedi, H. et al. Implementation and Outcomes of a Molecular Tumor Board at Herbert-Herman Cancer Center, Sparrow Hospital. Acta Med. Acad. 48, 105-115 (2019).

60. Tsimberidou, A. M. et al. Long-term overall survival and prognostic score predicting survival: The IMPACT study in precision medicine. J. Hematol. Oncol. 12, 1-12 (2019).

61. Varnier, R. et al. Actionable molecular alterations in advanced gynaecologic malignancies: updated results from the ProfiLER programme. Eur. J. Cancer 118, 156-165 (2019).

62. Wheler, J. J. et al. Cancer therapy directed by comprehensive genomic profiling: A single center study. Cancer Res. 76, 3690-3701 (2016).

63. Worst, B. C. et al. Next-generation personalised medicine for high-risk paediatric cancer patients - The INFORM pilot study. Eur. J. Cancer 65, 91-101 (2016).

64. van de Haar, J., Hoes, L. \& Voest, E. Advancing molecular tumour boards: highly needed to maximise the impact of precision medicine. ESMO Open 4, e000516 (2019).

65. Kato, S. et al. Real-world data from a molecular tumor board demonstrates improved outcomes with a precision N-of-One strategy. Nat. Commun. 11, 4965 (2020).

66. Larson, K. L. et al. Clinical Outcomes of Molecular Tumor Boards: A Systematic Review. JCO Precis. Oncol. 1122-1132 (2021). doi:10.1200/PO.20.00495

67. Alix-Panabières, C. \& Pantel, K. Clinical Applications of Circulating Tumor Cells and Circulating Tumor DNA as Liquid Biopsy. Cancer Discov. 6, 479-491 (2016).

68. Alix-Panabières, C. The future of liquid biopsy. Nature 579, S9-S9 (2020).

69. Thakral, D. et al. Real-Time Molecular Monitoring in Acute Myeloid Leukemia With Circulating Tumor DNA. Front. Cell Dev. Biol. 8, (2020).

70. Bettegowda, C. et al. Detection of Circulating Tumor DNA in Early- and Late-Stage Human Malignancies. Sci. Transl. Med. 6, 224ra24-224ra24 (2014).

71. Yang, Y.-C. et al. Circulating tumor DNA detectable in early- and late-stage colorectal cancer patients. Biosci. Rep. 38, (2018).

72. Wu, C. C., Maher, M. M. \& Shepard, J.-A. O. Complications of CT-Guided 
medRxiv preprint doi: https://doi.org/10.1101/2021.10.07.21264241; this version posted December 9,2021 . The copyright holder for this preprint (which was not certified by peer review) is the author/funder, who has granted medRxiv a license to display the preprint in perpetuity.

It is made available under a CC-BY 4.0 International license.

Percutaneous Needle Biopsy of the Chest: Prevention and Management. Am. J. Roentgenol. 196, W678-W682 (2011).

73. Schütte, M. et al. Cancer Precision Medicine: Why More Is More and DNA Is Not Enough. Public Health Genomics 20, 70-80 (2017).

74. Hurst, C. D. \& Knowles, M. A. Multi-omic profiling refines the molecular view. Nat. Rev. Clin. Oncol. 15, 203-204 (2018).

75. Lu, M. \& Zhan, X. The crucial role of multiomic approach in cancer research and clinically relevant outcomes. EPMA J. 9, 77-102 (2018).

76. Kurnit, K. C. et al. Precision Oncology Decision Support: Current Approaches and Strategies for the Future. Clin. Cancer Res. 24, 2719-2731 (2018).

77. Yu, J. X., Upadhaya, S., Tatake, R., Barkalow, F. \& Hubbard-Lucey, V. M. Cancer cell therapies: the clinical trial landscape. Nat. Rev. Drug Discov. 19, 583-584 (2020).

78. Toma, M. et al. Paediatric Medicines in Europe: The Paediatric Regulation-Is It Time for Reform? Front. Med. 8, (2021).

79. European Medicines Agency and European Commission (DG Health and Food Safety) action plan on paediatrics. Action Plan on Paediatrics. (2020). Available at: https://www.ema.europa.eu/en/documents/report/european-medicines-agencyeuropean-commission-dg-health-food-safety-action-plan-paediatrics_en.pdf. (Accessed: 18th August 2021)

80. FDA. Enhancing the Diversity of Clinical Trial Populations - Eligibility Criteria, Enrollment Practices, and Trial Designs Guidance for Industry. (2020). Available at: https://www.fda.gov/regulatory-information/search-fda-guidancedocuments/enhancing-diversity-clinical-trial-populations-eligibility-criteria-enrollmentpractices-and-trial. (Accessed: 13th August 2021)

81. Al-Baimani, K. et al. Are Clinical Trial Eligibility Criteria an Accurate Reflection of a Real-World Population of Advanced Non-Small-Cell Lung Cancer Patients? Curr. Oncol. 25, 291-297 (2018).

82. Van Spall, H. G. C., Toren, A., Kiss, A. \& Fowler, R. A. Eligibility Criteria of Randomized Controlled Trials Published in High-Impact General Medical Journals. JAMA 297, 1233 (2007).

83. Liu, R. et al. Evaluating eligibility criteria of oncology trials using real-world data and Al. Nature 592, 629-633 (2021).

84. Kim, E. S. et al. Modernizing Eligibility Criteria for Molecularly Driven Trials. J. Clin. Oncol. 33, 2815-2820 (2015).

85. Kim, E. S. et al. Broadening Eligibility Criteria to Make Clinical Trials More Representative: American Society of Clinical Oncology and Friends of Cancer Research Joint Research Statement. J. Clin. Oncol. 35, 3737-3744 (2017).

86. Patel, N. M. et al. Enhancing Next-Generation Sequencing-Guided Cancer Care Through Cognitive Computing. Oncologist 23, 179-185 (2018).

87. Alexander, M. et al. Evaluation of an artificial intelligence clinical trial matching system in Australian lung cancer patients. JAMIA Open 3, 209-215 (2020).

88. Foundation, M. Clinical Research \& Trial Matching. (2021). Available at: https://www.foundationmedicine.com/service/clinical-research-and-trial-matching. (Accessed: 25th October 2021)

89. Schulz, K. F., Altman, D. G. \& Moher, D. CONSORT 2010 Statement: updated guidelines for reporting parallel group randomised trials. BMC Med. 8, 18 (2010). 
Insufficient tissue

Studies reporting $\mathrm{n}=32$

Patient attrition $14 \%$

\section{No mutations}

Studies reporting $\mathrm{n}=29$

Patient attrition $26 \%$

\section{No Actionable mutations}

Studies reporting $n=26$

Patient attrition $22 \%$

\section{Actionable but not treatment/}

\section{trial available}

Studies reporting $\mathrm{n}=16$

Patient attrition $6 \%$

\section{Actionable but ineligible for} treatment

Studies reporting $\mathrm{n}=17$

Patient attrition $4 \%$

\section{Off-licence treatment available}

\section{but not accessed}

Studies reporting $\mathrm{n}=7$

Patient attrition 5\%

\section{Actionable mutations}

Studies reporting $n=45$

Patient attrition $49 \%$
Yes

Review by MTB to determine eligibility for molecular profiling

No

Tissue acquisition archived/ biopsy/ surgery

Germline sample taken e.g. Blood/ Buccal

Eligible for

Yes profiling?
New tissue acquisition
Clinically deteriorated Studies reporting $n=31$

Patient attrition 15\%
Patients treated

Studies reporting $n=48$ Percentage of patients $20 \%$ 


\section{Patients treated}

Actionable Mutations $49 \%(n=9371 / 19132)$
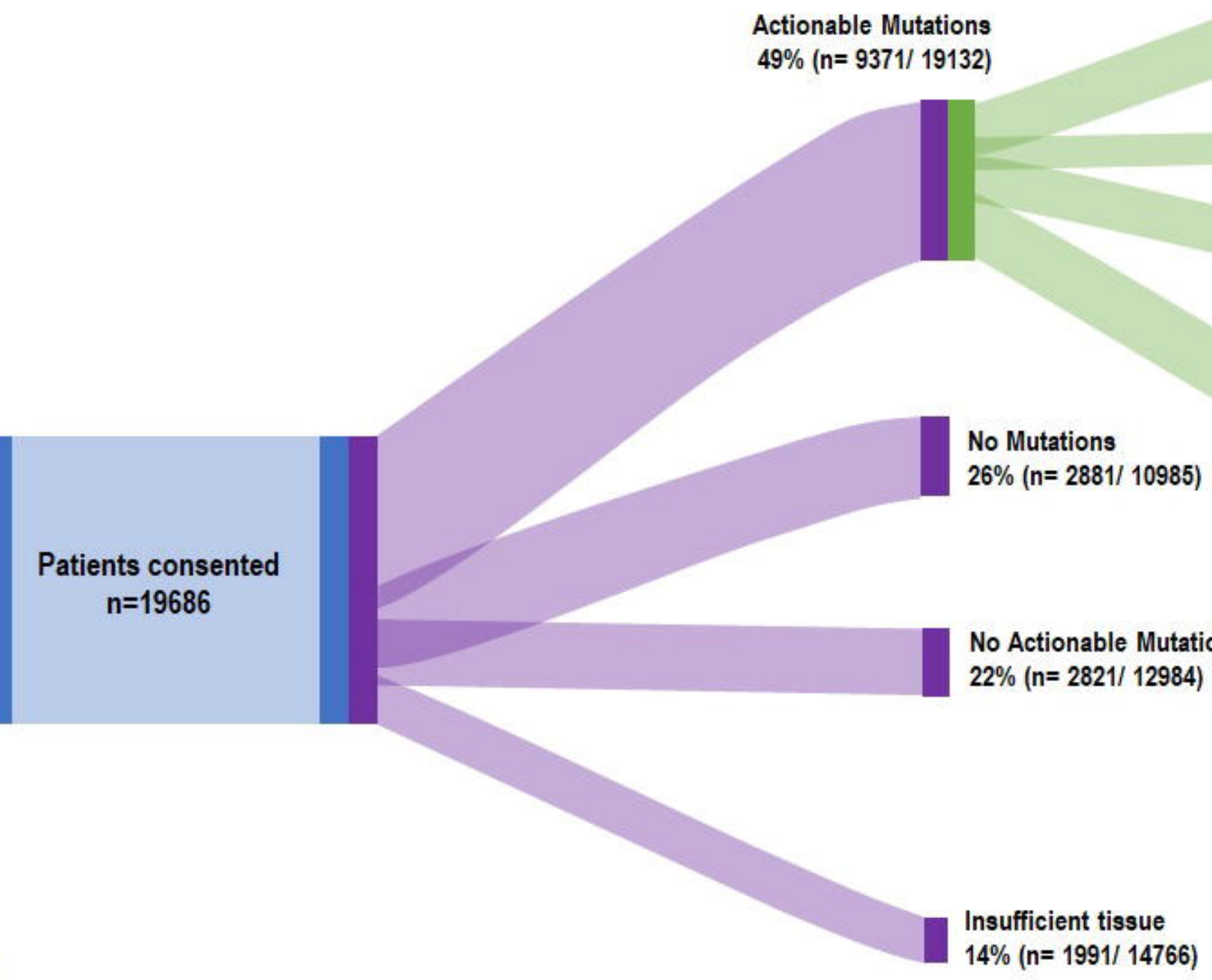

Actionable but ineligible for treatment $4 \%(n=386 / 10286)$

Actionable but no treatment/ trial available $6 \%(n=533 / 8475)$

Unknown

$29 \%(n=5725 / 19626)$

Insufficient tissue

$14 \%$ ( $n=1991 / 14766)$ 